\section{artelogie}

\section{Artelogie}

Recherche sur les arts, le patrimoine et la littérature de l'Amérique latine

$12 \mid 2018$

Idiosyncrasie de l'indigénisme en Amérique latine.

Pluralité des sources et des appropriations extra-

latino-américaines

\title{
Un hilo invisible : Un contrapunto hilvanado en el tiempo
}

Ma. Eugenia Méndez-Marconi

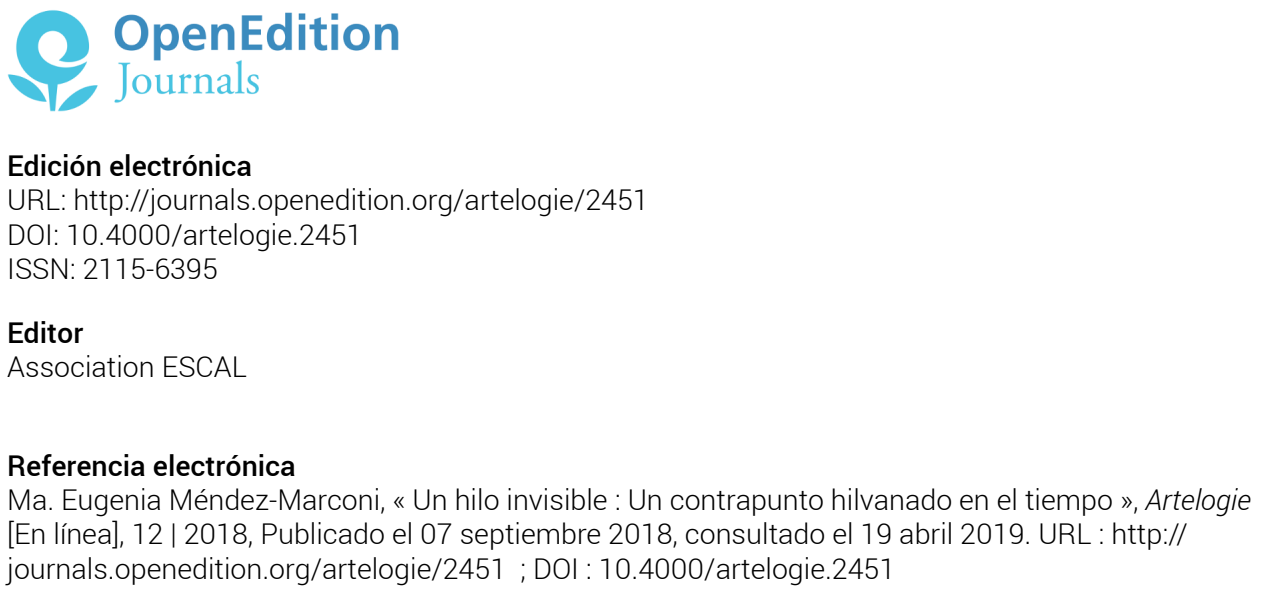

Este documento fue generado automáticamente el 19 abril 2019.

Association ESCAL 


\title{
Un hilo invisible : Un contrapunto hilvanado en el tiempo
}

\author{
Ma. Eugenia Méndez-Marconi
}

1 El arte de una cultura es una expresión sintética de la misma y -en muchos casosde su cosmovisión; por lo cual, es de gran interés seguir el diálogo entre los artistas de tiempos y culturas disímiles, vislumbrando el entramado invisible que los une.

2 Se propone establecer un diálogo en contrapunto entre los artistas contemporáneos Rank, Brítez y Larrosa, y los artistas anónimos de un remoto pasado precolombino; lo que implica un reconocimiento de los elementos opuestos en esencia y en lo visible, así como también encontrar aquellos puntos en común que los ligan.

3 Más allá de los elementos formales, las

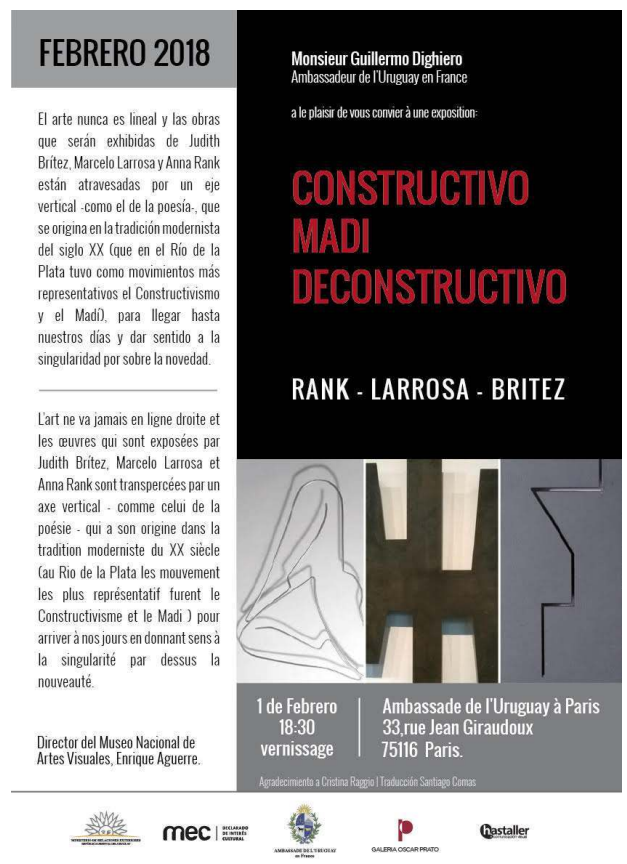
obras de arte toman su sentido en un contexto cultural ya que comprenden también una función social que ha variado según los tiempos y las culturas.

4 Las culturas precolombinas se caracterizaron por desarrollar su devenir diario en un denso entramado ritual, en el cual hasta los más ínfimos eventos tenían una contraparte en el cosmos, que se correspondía con inalterables realidades espirituales.

$5 \mathrm{El}$ arte moderno y post-moderno por el contrario, ocurre en sociedades profundamente carentes de mitos y por consecuencia "desritualizadas"; por lo cual, la obra de arte tiende a ser una singularidad por no funcionar en un contexto más amplio y profundo. 
6 El arte ritual se mueve en el contexto del simbolismo de una cultura, lo que deviene en un arraigo cultural. Por el contrario, el arte actual se desarrolla de manera tal que las imágenes no comprenden un simbolismo arraigado en un lenguaje colectivo.

7 Pese a estas diferencias, que se han desarrollado por los cambios en la forma de vida del hombre y de sus creencias, el arte ha ido transformándose como manifestación de esto; sin embargo, existe un hilo invisible que conecta el verdadero arte de todos los tiempos, y por ende los hace pertenecer a una tradición sin tiempo que es Universal.

Desde las primeras manifestaciones conocidas del arte, en esencia fueron expresiones sintéticas y abstractas, donde la labor del creador trabajaba en lo puro de las formas; por ende sea cual fuese la representación, el artista operaba en la armonización de los elementos formales absolutos, muchas veces desde una visión diáfana y directa de la naturaleza. Dichas relaciones además de contener un sentido estético, moral y espiritual profundo, entraban en el plano de la geometría, el cual no refiere a una imitación sino a la idea de construcción.

9 En estas ideas trabajó el Maestro Joaquín Torres García en gran parte de su producción artística y teórica, en su incansable búsqueda de una tradición del arte de América precolombina y del arte en sí mismo. En su texto "Tradición del Hombre Abstracto" (1938) escribió las siguientes líneas que dan cuenta de su concepción:

“Tradición del HOMBRE ABSTRACTO tradición de construcción. El hombre de todos los tiempos: junto al prehistórico, junto al primitivo, junto al azteca y el inca, junto al egipcio y el griego -en la Edad Media- allí estaba. La civilización de las edades, pasando: de la caverna a la arquitectura, de la superstición a la Filosofía, de la fuerza de la Justicia. Tradición del saber, incrustada en la piedra, oculta en el símbolo, verdad ayer y hoy, como el Sol.

[...] Antaño; tradición del saber, vida en la totalidad."

Las obras de estos tres artistas que hoy se presentan en conjunto, tienen como base común trabajar en el plano de la geometría, siendo esto un punto de encuentro con los artistas del remoto pasado precolombino; lo que los inspira a identificarse y alinearse con su espíritu pero desde nuevas configuraciones. Asimismo, crear sus obras con diversos materiales presenta una visión más integral del oficio artístico, como en muchas épocas sucedía.

11 Construyen sus obras, ensimismados en las relaciones de las formas, las líneas, las sucesiones rítmicas y el color, y en la estructura global que las armoniza en el plano frontal de la ortogonalidad que comprende a la Totalidad. Pero también, el artista opera con lo desconocido, con su intuición, y con lo sensible, su emoción.

Estos puntos de encuentro los hace estar ligados a esta tradición que les precede, en la cual los artistas de eras pretéritas crearon diversidades de obras que en esencia se correspondían en un espíritu geométrico, como sucede en este caso.

Apreciar estas obras nos implica un trabajo de observación y contemplación, que conllevan tiempos que en estas sociedades híper-dinámicas e híper-estimuladas por imágenes resulta difícil, pero deviene, como en otras épocas, en beneficio del Ser de cada persona, conectándose con la esencia misma que hace a estas piezas atemporales. 


\section{RESÚMENES}

Se propone establecer un diálogo en contrapunto entre los artistas contemporáneos Rank, Brítez y Larrosa, y los artistas anónimos de un remoto pasado precolombino; lo que implica un reconocimiento de los elementos opuestos en esencia y en lo visible, así como también encontrar aquellos puntos en común que los ligan.

\section{AUTOR}

\section{MA. EUGENIA MÉNDEZ-MARCONI}

Ma. Eugenia Méndez-Marconi, Museóloga (Universidad de la República), Docente G1 Instituto Escuela Nacional de Bellas Artes (Universidad de la República), Docente Comunicación Visual y Artes Plásticas (Educación Secundaria), Exposiciones e investigación en la Fundación José Gurvich - Museo Gurvich, Artista plástica. 